Several explanations have been proposed to explain these divergent results - failure to define the population being studied; differing, possibly incorrect methods of sample collection; failure to obtain truly "normal" subjects for control purposes, etc. To avoid these various criticisms we have studied a group of normal, asymptomatic women who had not been hospitalized and compared the findings with those in three groups of patients, the pattern of whose illness had been carefully defined by long-term follow-up in a specialist urinary infection clinic. To reduce sampling errors and to define the regular carrier state of these women each was studied weekly for five or six weeks. To exclude the possible influence of recent infection (Marsh et al., 1972) or antibiotic treatment or a changing state before subsequent infection (Stamey et al., 1971) all the patients were known to have had no bacteriuria or antibiotics for six weeks before the study and no bacteriuria during or within six weeks of completion of the study.

The results show no difference in the introital carriage rate of $E$. coli between normal subjects and patients referred with a history of previous urinary infection whether they were subsequently shown to be intermittently bacteriuric, symptomatic and abacteriuric, or asymptomatic and abacteriuric. A small difference in periurethral carriage of enterobacteria in general was observed between normal subjects and the patient groups though there was no difference between the patient groups. Thus it does seem that patients with a previous history of urinary infection may have a slight change in the overall periurethral colonization as compared with normal women but that there is no difference in this respect between those who are subsequently intermittently bacteriuric and those who are persistently abacteriuric. Furthermore, though $E$. coli was the most common cause of bacteriuria in our patients no difference in the periurethral carriage rate was observed between the normal subjects and the three patient groups. There was also no difference in the recovery rate or persistence of particular $E$. coli serotypes.

When these results are compared with other reports it must be noted that slightly differing techniques are used. Thus Stamey et al. (1971) studied clean-catch urethral urine samples (labelled $\mathrm{vB}_{1}$ ) and samples from the vaginal vestibule, Bailey et al. (1973) studied swabs from the external urethral meatus (periurethral swabs) and vaginal vestibule, and Cox et al. (Cox, 1966; Cox et al., 1968) obtained urethral specimens using a specially designed instrument. We have previously used the term "introital" swab to define what is more correctly a periurethral swab. We have also previously shown and subsequently confirmed that colony counts of the same organism are obtained in the same proportion of instances from urethral urine $\left(\mathrm{VB}_{1}\right)$ and periurethral swabs in normal women and patients alike.

By dividing patients into "persistent", "intermittent," and "non-" carriers of introital bacteria on the basis of swabs taken at clinic attendances we previously showed (O'Grady et al., 1970) that recurrent infection was more frequent in "persistent" carriers. Though we excluded swabs taken at the time or within two or three days of infection the work of Stamey et al. (1971) suggests that this period may be insufficient to exclude periods of introital carriage directly related to episodes of infection. In the present study we sought to establish whether introital carriage was a special feature of women with lower urinary tract symptoms when care was taken to examine swabs only at times remote from urinary infection. We found no evidence of unusual carriage on serial study during interinfected periods and it appears, therefore, that there is little practical advantage in attempting to define patients who regularly have a high periurethral enterobacterial carriage rate in the hope that identification of such patients might indicate those who are at particular risk from recurrent bacteriuria or lead to treatment of the introitus which might in turn reduce the potential for recurrent reinfection or, in the case of patients with the urethral syndrome, eliminate their symptoms.

We are indebted to the board of governors and the joint research board, St. Bartholomew's Hospital, and to the North-east Metropolitan Regional Hospital Board for grants towards the cost of this work. We should also like to acknowledge the statistical advice given by Miss A. J. Macfarlane, M.R.C. Air Pollution Unit, Medical College, St. Bartholomew's Hospital.

\section{References}

Bailey, R. R., et al. (1973). Lancet, 2, 275.

Bettelheim, K. A., and Taylor, J. (1969). Fournal of Medical Microbiology, 2, 225

Cattell, W. R., et al. (1971). British Medical fournal, 1, 377.

Cox, C. E. (1966). Southern Medical fournal, 59, 621

Cox, C. E., Lacy, S. S., and Hinman, F. (1968). Fournal of Urology, 99, 632.

Gruneberg, R. N., Leigh, D. A., and Brumfitt, W. (1968). In Urinary Tract Infection, ed. F. O'Grady, and W. Brumfitt, p. 68. London, Oxford University Press.

Marsh, F. P., Murray, M., and Panchamia, P. (1972). British fournal of Urology, 44, 368 .

O'Grady, F. W., et al. (1970). Lancet, 2, 1208.

Stamey, T. A., et al. (1971). California Medicine, 115, 1.

\title{
Adrenergic, Coagulation, and Fibrinolytic Responses to Heat
}

\section{B. J. BRITTON, CHRISTINE HAWKEY, W. G. WOOD, MURIEL PEELE, J. KAYE, M. H. IRVING}

British Medical fournal, 1974, 4, 139-141

\section{Summary}

Two groups of volunteers were exposed to heat in a sauna bath-one group for 10 minutes and the other for 15. There

\footnotetext{
Department of Surgery, St. Bartholomew's Hospital, London EC1A 7BE

B. J. BRITTON, M.B., F.R.c.s., Lecturer in Surgery

W. G. WOOD, B.SC., PH.D., Biochemist

MURIEL PEELE, A.I.M.L.T., Research Technician

M. H. IRVING, M.D., F.R.C.S., Assistant Director, Surgical Professorial Unit

Department of Chemical Pathology, St. Bartholomew's Hospital, London EC1A 7BE

J. KAYE, M.SC., M.C.B., Senior Biochemist

Nuffield Institute of Comparative Medicine, London Zoo, London N.W.1

CHRISTINE HAWKEY, B.SC., PH.D., Head of Haematology Section
}

was no change in plasma adrenaline concentration until the subjects emerged from the sauna bath, when there was a slight increase in concentration. Factor VIII and thromboelastograph patterns did not change but marked activation of fibrinolysis , was stimulated by exposure to heat. These findings support the concept that fibrinolysis is not mediated by direct adrenergic activity.

\section{Introduction}

The factors that initiate the changes in coagulation and fibrinolysis which occur during stress situations such as surgery have still not been elucidated. Many years ago it was suggested that adrenaline played a significant role in the activation of coagulation and fibrinolysis (Cannon and Gray, 1914; Biggs et al., 1947). More recently the advent of the 
beta-adrenergic blocking drugs has renewed interest in this subject though experiments attempting to prevent stressinduced changes in coagulation and fibrinolysis with these drugs have given conflicting results (Cohen et al., 1968; Cash et al., 1970).

Study of this presumed association is difficult because of the problem of administering a controlled adrenergic stimulus. The intravenous infusion of adrenaline into volunteers has been used but has disadvantages, both ethical and practical. On the other hand, the monitoring of the adrenergic response to trauma such as surgery is difficult because of the intermittent and variable nature of the response.

Recent studies indicating that a short period of exposure to intense heat caused an increase in plasma adrenaline levels were thus of great interest (Taggart et al., 1972). This situation seemed to induce a controlled adrenergic stimulus and was thus apparently suitable for study of the coagulation and fibrinolytic changes accompanying a rise in the plasma adrenaline level.

We report here the adrenergic, coagulation, and fibrinolytic status of two groups of male volunteers before, during, and after exposure to intense environmental heat.

\section{Methods}

In the first study seven healthy male volunteers aged between 25 and 36 (mean 29.0) years were rested on a couch for 15 minutes before exposure to heat. At the end of the rest period pulse and axillary temperature were recorded and a blood sample obtained from a convenient antecubital vein using a two-syringe technique with minimal stasis. Electrocardiograph leads were attached to the subjects and they then walked into the sauna and sat down. The dry bulb temperature of the bath was between $90^{\circ} \mathrm{C}$ and $110^{\circ} \mathrm{C}$. Two further blood samples were taken while the subjects were still in the sauna, five and 10 minutes after entry.

The second study involved five healthy male volunteers aged 26 to 31 years (mean 28.6 years) who were investigated in a similar manner but subjected to 15 minutes heat in the sauna. Blood samples were taken before entering the sauna, after seven and 15 minutes inside the bath, and on coming out of the sauna.

On each occasion $20 \mathrm{ml}$ of blood was taken into the first syringe for biochemical analysis. $10 \mathrm{ml}$ was used for catecholamine estimation and this blood was placed in lithium heparin tubes to which sodium metabisulphite was added as an antioxidant. The sample was then immediately centrifuged and the resulting plasma separated and frozen at $-76^{\circ} \mathrm{C}$ for analysis within the next seven days. .Total catecholamines and noradrenaline were determined in the sample by the semi-automated fluorimetric method of McCullough (1968) which uses the differential stabilization of the trihydroxyindole derivatives of adrenaline and noradrenaline at the same excitation wave length.

The remaining $10 \mathrm{ml}$ of blood was put into a lithium Sequestrene tube and centrifuged. The plasma was frozen for subsequent analysis of triglycerides, free fatty acids, and cholesterol. Triglycerides were measured fluorimetrically by the semi-automated method of Cramp and Robertson (1968) and free fatty acids by a semi-automated modification of the Dole method (Carruthers, 1974). Cholesterol was measured by the colorimetric method of Annan and Isherwood (1969).

Blood coagulation and fibrinolytic studies were carried out on $9 \mathrm{ml}$ of blood taken into a second syringe containing $1 \mathrm{ml}$ of $3.8 \%$ sodium citrate. The samples were placed on melting ice and the tests carried out without delay. Euglobulin lysis time was determined by a modification of the method of Buckell (1958) and the results were expressed as percentage change from control. Thromboelastography was carried out according to the method of Hardisty and Macpherson (1962). Blood for estimation of fibrin degradation products (F.D.P.) was placed in a glass tube containing thrombin $(50 \mathrm{U} / 2$ $\mathrm{ml}$ blood) and aprotinin (500 $\mathrm{U} / 2 \mathrm{ml}$ blood), and the measurement was made using the tanned red cell haemagglutination inhibition test of Merskey et al. (1969). Partial thromboplastin time was measured by the method of Rodman et al. (1958). Packed cell volume was determined on duplicate samples of heparinized blood using the Hawkesley microhaematocrit method.

The results of the second study were submitted to statistical analysis using an analysis of variance.

\section{Results}

The results of the first study are shown in table I. Exposure to the intense heat of the sauna for a period of 10 minutes caused the pulse rate to increase from a mean rate ( \pm S.D.) of $70+9$ to a rate of $133+17$ while packed cell volume remained stable between $42 \%$ and $43 \%$. Plasma total catecholamines did not change significantly, the mean presauna level being $0.49 \pm 0.24 \mu \mathrm{g} / \mathrm{l}$. while the value after 10 minutes in the sauna bath was $0.63 \pm 0.47 \mu \mathrm{g} / \mathrm{l}$. Breakdown of this value showed the adrenaline level to be $0.13 \pm 0.09 \mu \mathrm{g} / \mathrm{l}$. in the control period and $0.14 \pm 0.11 \mu \mathrm{g} / \mathrm{l}$. after 10 minutes heat. Other biochemical indices showed little change, there being insignificant increases in free fatty acids and no change in cholesterol or plasma triglyceride.

TABLE I-Mean Changes ( \pm S.D.) in Haematological and Biochemical Values before and during Exposure of Seven Men to 10 Minutes Heat in Sauna Bath

\begin{tabular}{|c|c|c|c|}
\hline & $\begin{array}{l}\text { Before } \\
\text { Sauna }\end{array}$ & $\begin{array}{l}5 \text { Minutes' } \\
\text { Exposure }\end{array}$ & $\begin{array}{c}10 \text { Minutes' } \\
\text { Exposure }\end{array}$ \\
\hline $\begin{array}{l}\text { Pulse rate/min } \\
\text { P.C.V. (\%) } \\
\text { Euglobulin lvsis time (\% change) } \\
\text { Factor VIII (\%) } \\
\text { Thromboelastograph r }(\mathrm{sec}) \\
\text { Thromboelastograph K }(\mathrm{sec}) \\
\text { Partial thromboplastin time }(\mathrm{sec}) \\
\text { Fibrin degradation products } \\
\text { Total catecholamines ( } \mu \mathrm{g} / \mathrm{l} .) \\
\text { Noradrenaline }(\mu \mathrm{g} / 1 .) \\
\text { Adrenaline }(\mu \mathrm{g} / 1 .) \\
\text { Cholesterol }(\mathrm{mg} / 100 \mathrm{ml}) \\
\text { Free fatty acids }(\mu \mathrm{mol} / 1 .) \\
\text { Triglyceride }(\mathrm{mg} / 100 \mathrm{ml})\end{array}$ & $\begin{array}{c}70 \pm 9 \\
42 \pm 3 \\
100 \pm 0 \\
90 \pm 19 \\
493 \pm 68 \\
291 \pm 54 \\
87 \pm 12 \\
2 \cdot 3 \pm 0 \cdot 24 \\
0 \cdot 49 \pm 0 \cdot 24 \\
0.36 \pm 0 \cdot 26 \\
0 \cdot 13 \pm 0 \cdot 09 \\
181 \pm 39 \\
504 \pm 110 \\
84 \pm 40\end{array}$ & $\begin{array}{l}118 \pm 13 \\
43 \pm 2 \\
107 \pm 28 \\
113 \pm 41 \\
525 \pm 55 \\
341 \pm 59 \\
84 \pm 11 \\
2 \cdot 3 \pm 1 \cdot 14 \\
0 \cdot 27 \pm 1 \cdot 14 \\
0 \cdot 20 \pm 0 \cdot 17 \\
0 \cdot 07 \pm 0.04 \\
191 \pm 46 \\
546 \pm 176 \\
85 \pm 46\end{array}$ & $\begin{array}{c}133 \pm 17 \\
43 \pm 2 \\
81 \pm 23 \\
125 \pm 42 \\
545 \pm 57 \\
293 \pm 66 \\
85 \pm 9 \\
2 \cdot 3 \pm 0 \cdot 47 \\
0 \cdot 63 \pm 0 \cdot 47 \\
0 \cdot 49 \pm 0 \cdot 40 \\
0 \cdot 14 \pm 0 \cdot 11 \\
187 \pm 44 \\
624 \pm 196 \\
85 \pm 45\end{array}$ \\
\hline
\end{tabular}

Coagulation and fibrinolytic values similarly showed little change in response to 10 minutes intense heat. Factor VIII showed an insignificant rise from $90 \pm 19 \%$ to $125 \pm 42 \%$ and the partial thromboplastin time was stable at $87 \pm 12$ seconds control and $85 \pm 9$ seconds after heat. The thromboelastograph $r$ time showed an insignificant rise while $K$ did not change at all.

Euglobulin olot lysis time fell from $100 \%$ to a mean of $81 \pm 23 \%$ after heat while fibrin degradation products remained unchanged throughout.

\section{STUDY 2}

In this series the exposure to heat was increased by five minutes to 15 minutes and the volunteers were also studied after they had left the sauna bath. The results are shown in table II.

Mean pulse rate rose from a control level of $86 \pm 7$ to $137 \pm 17$ after 15 minutes heat and fell to $114 \pm 17$ on leaving the bath $(P<0.005)$.

In this series total catecholamines rose slightly from a mean of $0.51 \pm 0.09 \mu \mathrm{g} / \mathrm{l}$. to $0.55 \pm 0.11 \mu \mathrm{g} / 1$. after 15 minutes heat, there being no change after leaving the bath. When this was broken down into noradrenaline and adrenaline, however, a change was observed. Though plasma adrenaline 
TABLE II-Mean Changes ( \pm S.D.) in Haematological and Biochemical Values before, during, and after Exposure of Five Men to 15 Minutes Heat in Sauna Bath

\begin{tabular}{|c|c|c|c|c|}
\hline & $\begin{array}{l}\text { Before } \\
\text { Sauna }\end{array}$ & $\begin{array}{l}7 \text { Minutes' } \\
\text { Exposure }\end{array}$ & $\begin{array}{c}15 \text { Minutes' } \\
\text { Fxposure }\end{array}$ & $\begin{array}{l}\text { After } \\
\text { Sauna }\end{array}$ \\
\hline $\begin{array}{l}\text { Pulse rate/min } \\
\text { P.C.V. }(\%) \\
\text { Euglobulin lysis time }\end{array}$ & $\begin{array}{c}86 \pm 7 \\
42 \cdot 5 \pm 1 \cdot 5 \\
100 \pm 0\end{array}$ & $\begin{array}{c}127 \pm 12 \\
42 \cdot 8 \pm 1 \cdot 3 \\
84 \pm 16\end{array}$ & $\begin{array}{c}137 \pm 17 \\
43 \cdot 5 \pm 2 \cdot 0 \\
67 \pm 13\end{array}$ & $\begin{array}{l}114 \pm 17 \\
44 \cdot 5 \pm 1 \cdot 8 \\
48 \pm 5\end{array}$ \\
\hline $\begin{array}{l}\text { (\% change) } \\
\text { Factor VIII (\%) } \\
\text { Thromboelastograph r } \\
\text { (sec) }\end{array}$ & $\begin{array}{c}75 \pm 19 \\
570 \pm 112\end{array}$ & $\begin{array}{c}80 \pm 4 \\
534 \pm 54\end{array}$ & $\begin{array}{c}87 \pm 9 \\
516 \pm 33\end{array}$ & $\begin{array}{c}87 \pm 6 \\
540 \pm 82\end{array}$ \\
\hline Thromboelastograph $\mathrm{K}$ & $282 \pm 78$ & $279 \pm 73$ & $276 \pm 72$ & $273 \pm 43$ \\
\hline Total catecholamines & $0.51 \pm 0.09$ & $0.62 \pm 0.11$ & $0.55 \pm 0.11$ & $0.56 \pm 0.16$ \\
\hline $\begin{array}{l}\text { Noradrenaline }(\mu \mathrm{g} / \mathrm{l} .) \\
\text { Adrenaline }(\mu \mathrm{g} / 1 .) \\
\text { Cholesterol }(\mathrm{mg} / 100 \mathrm{ml}) \\
\text { Free fatty acids }(\mu \mathrm{mol} / 1 .) \\
\text { Triglyceride }(\mathrm{mg} / 100 \mathrm{ml})\end{array}$ & $\begin{array}{l}0.43 \pm 0.06 \\
0.09 \pm 0.06 \\
150 \pm 32 \\
635 \pm 359 \\
64 \pm 5\end{array}$ & $\begin{array}{l}0 \cdot 53 \pm 0 \cdot 14 \\
0 \cdot 09 \pm 0 \cdot 04 \\
166 \pm 30 \\
721 \pm 487 \\
64 \pm 5\end{array}$ & $\begin{array}{l}0 \cdot 48 \pm 0 \cdot 11 \\
0 \cdot 07 \pm 0 \cdot 04 \\
167 \pm 35 \\
709 \pm 430 \\
67 \pm 5\end{array}$ & $\begin{array}{l}0 \cdot 37 \pm 0 \cdot 15 \\
0 \cdot 19 \pm 0 \cdot 07 \\
170 \pm 27 \\
720 \pm 264 \\
67 \pm 5\end{array}$ \\
\hline
\end{tabular}

did not change during the time in the sauna bath $(0.09 \pm$ $0.06 \mu \mathrm{g} / 1$. control to $0.07 \pm 0.04 \mu \mathrm{g} / \mathrm{l}$. after 15 minutes) there was a rise in plasma adrenaline level to $0.19 \pm 0.07$ $\mu \mathrm{g} / 1$. when the volunteers left the bath $(P<0.05)$. This coincided with fainting in two of the five volunteers. Plasma cholesterol, triglyceride, and free fatty acids did not change significantly.

Evidence of change in some of the coagulation and fibrinolytic indices was greater after this longer period of exposure to heat. The euglobulin clot lysis time used as an index of fibrinolytic activity showed a significant fall from its control value of $100 \%$ to $67 \pm 13 \%$ after 15 minutes in the bath, with a further fall to $48 \%+5 \%$ outside the sauna afterwards $(P<0.001)$. This change showed a straight-line relationship with time and was accompanied by an increase in body temperature from $36.5^{\circ} \mathrm{C}$ to $38.5^{\circ} \mathrm{C}$. The packed cell volume had inoreased from a control value of $42.5 \pm$ $1.5 \%$ to $44.5 \pm 8 \%$ while the factor VIII showed an insignificant increase from $75 \pm 19 \%$ to $87 \pm 9 \%$ after 15 minutes heat and no further change on leaving the bath $(P=0.05)$. The thromboelastograph $r$ value fell from $570 \pm$ 112 seconds to $516+33$ seconds after 15 minutes heat but rose to $540 \pm 82$ seconds on leaving the bath. The change in the $K$ value was less marked. No change was observed in the level of F.D.P.

\section{Discussion}

The most obvious manifestation of the changes in coagulation and fibrinolysis that accompany injury is the development of venous thrombosis. Though in recent years much effort has been expended in studying the incidence of venous thrombosis and evaluating methods of prevention little attention seems to have been paid to the cause of the condition. Though Virchow's triad has remained unchallenged since it was propounded (Virchow, 1860) emphasis on the various parts of the trinity has changed. Recently the importance of hypercoagulability has been re-emphasized and in particular the role of systemic factors (Gallus et al., 1973).

Though Cannon and Gray (1914) and Forwell (1955) were convinced of the importance of adrenaline in causing hypercoagulability of the blood in stress situations the experimental methods available to them were relatively unrefined. Even today, with more sophisticated techniques, it is still difficult to prove an association between adrenergic activity and the coagulation/fibrinolytic mechanisms. The principal difficulty is to obtain an endogenous adrenergic stimulus relatively uncomplicated by other metabolic and physiological changes. Though useful information has been gained from studying operative stress and maximal exercise these situations are accompanied by many other responses and influenced by many factors. The findings by Taggart et al.
(1972) of a rise in adrenaline alone in conditions of extreme environmental heat thus seemed to be of particular value.

It was, therefore, disappointing in our first study to find that we were unable to reproduce a rise in adrenaline obtained by these workers. Initially we considered that the stimulus was insufficient though it was administered in the same manner and in the same sauna used by Taggart and his colleagues. The findings of our second study, however, clearly showed the cause of the difference. The significant rise in adrenaline that occurred in our second series did so only when the subjects had stepped out of the sauna bath and examination of Taggart's results show that this second postsauna sample was also taken after subjects had left the sauna bath. Some care must be taken in the interpretation of our findings, however, for though there was a statistically significant change in adrenaline the actual change was not gross and could well have been within the error of the method. If the finding is biologically significant it is likely that the cause of the rise in adrenaline is a combination of the adrenergic response induced in a vasodilated subject by standing up together with the stimulus of coming from a hot into a cooler environment. This finding does not, of course, lessen the possible serious consequences that may occur from such an adrenergic stimulus in a patient with cardiac disease.

The coagulation and fibrinolytic changes in these studies are of great interest. It is now fairly well established that factor VIII can be activated by an adrenergic stimulus (Prentice et al. 1969; Ingram et al., 1972), but the evidence for activation of fibrinolysis by adrenaline is much less clear.

Our studies show that there was no change in factor VIII in most subjects in response to heat, as would be expected if adrenaline was a prime factor in its activation. The lack of change in factor VIII on coming out of the sauna when there was a rise in adrenaline conflicts with this suggestion and could mean that no significance should be attached to the change in adrenaline. On the other hand, fibrinolytic activity was marked and progressively activated by heat. This activation occurred in the absence of an adrenergic stimulus and refutes a previous suggestion that the decreased fibrinolytic response seen in heat-acclimatized subjects is due to reduced adrenaline release (Bedrak et al., 1964).

The effect of environmental heat on postoperative changes in the fibrinolytic mechanism may not be insignificant for it is generally known that venous thrombosis is less common in tropical and subtropical countries (Hassen et al., 1973). This could be due to racial differences, but these could not account for the difference in the incidence of venous thrombosis observed between Brisbane and Sydney (Williams et al., 1973). Fibrinolysis is important in the prevention of postoperative venous thrombosis (Mansfield, 1972, Gordon-Smith et al., 1974) and while it may become possible to inhibit the coagulation changes occurring during surgery with betaadrenergic blockade (Britton et al., 1974) it would be important to leave fibrinolysis unaffected if thrombosis is to be prevented. These studies suggest that increased fibrinolytic activity is mediated by vasodilatation and consequent exposure of vascular endothelium to increased blood flow, rather than being a direct effect of adrenergic activity.

We thank the British Heart Foundation for support (Grant No. 341 and 343) and Mr. A. Murray for allowing us to use this sauna bath at the City Gymnasium.

\section{References}

Annan, W., and Isherwood, D. M. (1969). Fournal of Laboratory Technology, 26, 202.

Bedrak, E., Beer, G., and Furman, K. I. (1964). Fournal of Applied Physiology, 19,469

Biggs, R., Macfarlane, R. G., and Pilling, J. (1947). Lancet, 1, 402.

Britton, B. J., et al. (1974). British fournal of Surgery. In press. 
Buckell, M. (1958). Fournal of Clinical Pathology, 11, 403

Cannon, W. B., and Gray, H. (1914). American fournal of Physiology, 34, 232.

Carruthers, M. (Technicon, 1974). In Automation in Analytical Chemistry, ed. L. T. Skeggs. London.

Cash, J. D., Woodfield, D. G., and Allan, A. G. E. (1970). British fournal of

Haematology, 18, 487.
Cohen, R. J., et al. (1968). Lancet, 2, 1264.

Cramp, D., and Robertson, G. (1968). Analytical Biochemistry, 25, 246.

Forwell, G. D. (1955). Study in the Coagulation of the Blood with Special Reference to the Effects of Emotion and Adrenaline. Ph.D. Thesis. University of Edinburgh.

Gallus, A. S., Hirsch, J., and Gent, M. (1973). Lancet, 2, 805.

Gordon-Smith, I. C., Hickman, J. A., and Le Quesne, L.B. (1974). British Fournal of Surgery, 61, 213.

Hardisty, R. N., and Macpherson, J. C. (1962). Thrombosis et Diathesis Haemorrhagica, 7, 215.
Hartert, H. (1948). Klinische Wochenschrift, 26, 577.

Hassan, M. A., Rahman, E. A., and Rahman, I. A. (1973). British Medical Fournal, 1, 515.

Ingram, G. I. C., et al. (1972). British fournal of Haematology, 23, 266.

Mansfield, A. O. (1972). British Fournal of Surgery, 59, 754.

McCullough, H. (1968). Fournal of Clinical Pathology, 21, 759

Merskey, C., Lalezari, P., and Johnson, A. J. (1969). Proceedings of the Society for Experimental Biology and Medicine, 131, 871.

Prentice, C. R. M., et al. (1969). British fournal of Haematology, 17, 611.

Rodman, N. F., Barrow, E. M., and Graham, J. B. (1958). American fournal of Clinical Pathology, 29, 525.

Taggart, P., Parkinson, P., and Carruthers, M. (1972). British Medical Fournal, 3, 71 .

Virchow, R. (1860). Cellular Pathology as based on Physiological and Pathological Histology, trans F. Chance. London, Churchill.

Williams, O. B., McCaffrey, J. F., and Lau, O. J. (1973). British Medical Fournal, 1, 517.

\section{MEDICAL MEMORANDA}

\section{Multiple Coagulation Abnormalities in a Case of Cryptogenic Splenomegaly}

\author{
N. E. STATHAKIS, \\ A. G. PAPAYANNIS, \\ J. DERVENOULAS, \\ Ph. SCLIROS, \\ C. GARDIKAS
}

British Medical fournal, 1974, 4, 142-143

We describe here a case of cryptogenic splenomegaly of 20 years duration associated with acquired haemorrhagic diathesis. The study of the blood coagulation and fibrinolysis mechanism of this patient showed multiple abnormalities compatible with chronic defibrination syndrome. Splenectomy resulted in complete clinical cure and disappearance of the abnormal findings on laboratory tests.

\section{Case Report}

A 57-year-old man was admitted to hospital on 12 September 1972 because of prolonged bleeding after tooth extraction. There was no family history of bleeding or anaemia. He had had malaria when he was 21 and pulmonary tuberculosis when he was 23. Haemorrhagic manifestations began at 36 years when appendiceotomy was complicated by prolonged bleeding from the operative site. At that time marked splenomegaly was found. Since then he had frequent and severe epistaxes which when he was 42 and 53 necessitated admission into hospital and treatment with blood transfusions. During the second stay in hospital a mild thrombocytopenia $\left(80,000\right.$ platelets $\left./ \mathrm{mm}^{3}\right)$ was found. Excessive bleeding, lasting for more than 10 days, resulted from scaling of tartar when he was 40 and tooth extraction when he was 45 and 50 .

Five days before admission he had had a tooth extracted. The day before extraction laboratory studies showed: packed cell volume (P.C.V.) 37\%, haemoglobin $11.2 \mathrm{~g} / 100 \mathrm{ml}$, W.B.C. $8,000 / \mathrm{mm}^{3}$ with normal differential, platelets $250,000 / \mathrm{mm}^{3}$, bleeding time $2 \mathrm{~min}$ (Duke), and prothrombin time $17 \mathrm{sec}$ (control $13 \mathrm{sec}$ ). The tooth extraction was followed by excessive bleeding. On admission he continued to bleed. He was anaemic and a greatly enlarged and firm spleen was palpable $10 \mathrm{~cm}$ below the left costal margin. The remainder of the clinical examination showed nothing

Professorial Medical Unit, Evangelismos Hospital, Athens 140 Greece

N. E. STATHAKIS, M.D., Research Fellow

A. G. PAPAYANNIS, M.D., Senior Registrar in Haematology

J. DERVENOULAS, M.B., CH.B., Research Assistant

Ph. SCLIROS, M.D, Senior Registrar

C. GARDIKAS, M.D., PH.D., Professor of Medicine abnormal. The laboratory studies on admission showed: P.C.V. $24 \%$, haemoglobin $8.6 \mathrm{~g} / 100 \mathrm{ml}$, W.B.C. $10,800 / \mathrm{mm}^{3}$ with normal differential, and platelets $80,000 / \mathrm{mm}^{3}$. Serum iron was $25 \mu \mathrm{g} / 100$ $\mathrm{ml}$, and the total iron binding capacity was $380 \mu \mathrm{g} / 100 \mathrm{ml}$. The peripheral blood smear showed marked hypochromia and the bone marrow smear was normal but without stainable iron. Serum bilirubin was $0.7 \mathrm{mg} / 100 \mathrm{ml}$ and serum haptoglobins $40 \mathrm{mg} / 100$ $\mathrm{ml}$. The results of the autohaemolysis, Coombs's, and Motulsky's tests were negative, as were results of tests of osmotic fragility (direct and after 24 hours incubation at $37^{\circ} \mathrm{C}$ ) and heat-unstable and alkali-resistant haemoglobin. Haemoglobin electrophoresis was normal. A complete liver function evaluation and serum protein electrophoresis and immunoelectrophoresis showed nothing abnormal. Radiological examination of the bones and gastrointestinal tract, cholecystography, and pyelography also showed nothing abnormal. The spleen, besides its size, was characterized by the $x$-ray appearance of multiple puctiform foci of calcification (see fig.). The determination of surface radioactivity after administration of autologous red cells labelled with ${ }^{51} \mathrm{Cr}$ showed splenic sequestration of red cells.

The haemorrhage stopped 11 days after admission. During this period he was treated with local measures and transfusions of 